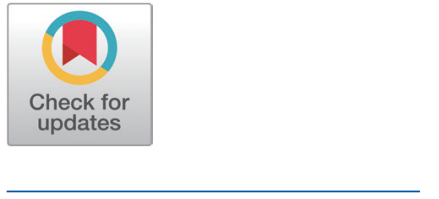

Received: Jun 23, 2020

Revised: Aug 4, 2020

Accepted: Aug 18, 2020

*Corresponding author

Hack-Youn Kim

Department of Animal Resources

Science, Kongju National University,

Yesan 32439, Korea.

Tel: +82-41-330-1241

E-mail: kimhy@kongju.ac.kr

Gye-Woong Kim

Department of Animal Resources

Science, Kongju National University,

Yesan 32439, Korea.

Tel: +82-41-330-1245

E-mail: kimgoong@kongju.ac.kr

Copyright $\odot 2020$ Korean Society of Animal Sciences and Technology.

This is an Open Access article distributed under the terms of the

Creative Commons Attribution

Non-Commercial License (http:// creativecommons.org/licenses/by$\mathrm{nc} / 4.0 /$ ) which permits unrestricted non-commercial use, distribution, and reproduction in any medium, provided the original work is properly cited.

ORCID

Sol-Hee Lee

https://orcid.org/0000-0003-1124-7095

Sung-Duck Joe

https://orcid.org/0000-0001-8637-3753

Gye-Woong Kim

https://orcid.org/0000-0001-7325-9898

Hack-Youn Kim

https://orcid.org/0000-0001-5303-4595

Competing interests

No potential conflict of interest relevant to this article was reported.

\section{Physicochemical properties of sausage manufactured with carp (Carassius carassius) muscle and pork}

\author{
Sol-Hee Lee, Sung-Duck Joe, Gye-Woong Kim* and Hack-Youn Kim* \\ Department of Animal Resources Science, Kongju National University, Yesan 32439, Korea
}

\begin{abstract}
The purpose of this study was to compare the physicochemical properties of sausage manufactured with carp (Carassius carassius) muscle and pork. Sausages were prepared using either $100 \%$ pork sausage (P10), a mixture of $50 \%$ pork and $50 \%$ carp muscle (P5C5), or $100 \%$ carp muscle (C10). The quality of the sausage emulsion was determined by analyzing approximate composition, $\mathrm{pH}$, instrumental color, cooking yield, water holding capacity (WHC), viscosity, and texture profile analysis (TPA). Moisture content of cooked $\mathrm{C} 10$ was significantly higher than that of P10 or P5C5 ( $p<0.05)$; however, protein content of cooked P10 was significantly higher than that of $\mathrm{C} 10(p<0.05)$. The $\mathrm{pH}$ of uncooked and cooked $\mathrm{C} 10$ was significantly higher than that of P10 and P5C5 ( $p<0.05)$. The cooking yield, WHC, and texture profile analysis of $\mathrm{C} 10$ were higher than those of P10 and P5C5 $(p<0.05)$. In addition, the viscosity of uncooked $\mathrm{C} 10$ was higher than that of $\mathrm{P} 10$ and $\mathrm{P} 5 \mathrm{C} 5$. These results suggest that carp muscle can enhance sausage quality with respect to $\mathrm{pH}$, WHC, cooking yield, viscosity, and TPA.
\end{abstract}

Keywords: Carp muscle, Pork, Emulsion sausage, Quality

\section{INTRODUCTION}

Processed fishery foods are categorized into dried, agar, paste, and seasoned products. Among them, fish paste products are often applied in home meal replacement (HMR) products, such as crab stick, crab meat, fish meat patty, and fish meat sausage [1]. Fish meat sausage is mainly produced using the washing method [2], although a variety of methods exists for the production of fish meat sausage in Korea. Pollack paste is increasingly consumed domestically and is frequently used in food production after removing the characteristic odor of fish meat [3].

Fish meat sausage is an emulsion-type product made using emulsified salt-soluble protein of fish muscle, fat, and heterogeneous proteins such as ISP (isolate soy protein), gelatin, etc. [4]. The quality of fish meat sausage is determined by its color, flavor, and elasticity, among which elasticity is the most important factor [5]. Elasticity can be altered by the quality of the main ingredient, fish species, type and amount of minor ingredients, and the cooking method. Researchers are currently investigating the potential use of new fish species other than the commonly used pollack, including common carp (Cyprinus 
Funding sources

This work was carried out with the support

of "Cooperative Research Program

for Agriculture Science \& Technology

Development (Project No. PJ01528103)",

Rural Development Administration, Korea.

Acknowledgements

Not applicable.

Availability of data and material

Upon reasonable request, the datasets

of this study can be available from the

corresponding author.

\section{Authors' contributions}

Conceptualization: Lee SH.

Data curation: Lee SH, Kim HY.

Formal analysis: Lee SH, Kim GW.

Methodology: Kim HY, Kim GW.

Software: Lee SH, Kim HY.

Validation: Lee SH.

Investigation: Lee SH, Joe SD, Kim GW, Kim HY.

Writing - original draft: Lee SH.

Writing - review \& editing: Lee SH, Joe SD, Kim GW, Kim HY

Ethics approval and consent to participate This article does not require IRB/IACUC approval because there are no human and animal participants. carpio) and crucian carp (Carassius carassius) [6].

Crucian carp is a fish species of the family Carassius, order Cyprinidea, and class Cypriniformes. The species is widely distributed across the Eurasian continent and is known to survive in almost all rivers in Korea. Crucian carps contain a substance that inhibits various adult diseases and reduces indigestion and fatigue. Approximately $75 \%$ of the essential amino acids in crucian carp consist of histidine, glycine, and lysine, three free amino acids that strongly influence the palatability of fish meat [7]. In Korea, crucian carp has been used in various medicinal foods mainly in the form of steamed fish, porridge, or soup [8-10].

Crucian carp is low in fat content and high in moisture content and it can be used to make lowfat and low-calorie sausage in food industry. Therefore, this study aimed to supplement the disadvantages of pork by preparing fish meat sausage using crucian carp.

\section{MATERIALS AND METHODS}

\section{Preparation of emulsion sausage}

The mixing ratio used to produce the fish meat sausage in this study is given in Table 1. The crucian carp (Carassius carassius) sample used in this study was obtained from the Wellbeing Fisheries in Chungcheongnam-do, Korea. The fish sample was stored at $2{ }^{\circ} \mathrm{C}$, and was prepared for the experiment within $12 \mathrm{~h}$ at the same temperature. The pork meat sample was taken from the rump, belly, and hock obtained $24 \mathrm{~h}$ after slaughter (NH hanaro, Yesan, Korea). The carp meat, pork meat, and back fat were ground using a grinder (PA-82, Mainca, Barcelona, Spain) to which a $3 \mathrm{~mm}$ plate was installed. Raw meat (60\%), back fat (20\%), and ice (20\%) were finely cut using a bowl cutter (K-30, Talsa, Valencia, Spain), and the preparation involved the addition of 1.2\% NPS, 1\% ISP, 1\% sugar, and $0.6 \%$ mixed spice per total weight. A filling device (EM-12, Mainca, Barcelona, Spain) was used to fill a natural pork intestine with the prepared emulsion, which was cooked for $30 \mathrm{~min}$ in an $80^{\circ} \mathrm{C}$ chamber (10.10ESI/SK, Alto Shaam, Menomonee Falls, WI, USA), followed by cooling for 20 min at $10^{\circ} \mathrm{C}$. The resulting fish meat sausage was stored at $4^{\circ} \mathrm{C}$ for subsequent experiments.

\section{Proximate composition}

The approximate composition was measured based on the AOAC [11]. The Kjeldahl method was used to analyze crude protein content, the Soxhlet method was used to determine crude fat content, the oven-drying method (at $105^{\circ} \mathrm{C}$ ) was used to analyze the moisture content, and the direct ashing

Table 1. Meat batter formulation with carp muscle and pork

\begin{tabular}{llccc}
\hline \multicolumn{1}{c}{ Ingredients } & P10 & P5C5 & C10 \\
\hline Main (\%) & & & & \\
& Meat & 60 & 30 & - \\
& Carp & - & 30 & 20 \\
& Fat & 20 & 20 & 20 \\
\hline Additive (\%) & Ice & 20 & 20 & \\
& NPS & 1.2 & & 1.2 \\
& Sugar & 1 & 1.2 & 1 \\
& Mixed spice & 0.6 & 0.6 & 1 \\
\hline
\end{tabular}

P10, 100\% pork; P5C5, 50\% pork and 50\% carp muscle; C10, $100 \%$ carp muscle. NPS, nitrite pickling salt; ISP, isolated soy protein. 
method was used to assess the crude ash content.

$\mathrm{pH}$

Cooked and uncooked meat batters were mixed with distilled water in a 1:4 ratio using Ultraturax, and the $\mathrm{pH}$ of the diluted sample was measured using a $\mathrm{pH}$ meter (S220, Mettler-Toledo, Switzerland) with a pre-installed contact-type electrode (ROSS Ultra pH Electrode 8135BNUWP, Thermo Scientific, Waltham, MA, USA).

\section{Color}

A colorimeter (CR 210, Minolta, Osaka, Japan) was used to measure the CIE L*, CIE a*, and CIE $\mathrm{b}^{*}$ values of an inner cross-section of the sausage. A white standard plate with the following reference colors was used: +97.83 for CIE L*, -0.43 for CIE $a^{*}$, and +1.98 for CIE $b^{*}$.

\section{Cooking yield}

The sample was weighed before cooking. Then, the meat was cooked for $30 \mathrm{~min}$ in a chamber set to $80^{\circ} \mathrm{C}$, following which it was cooled for $20 \mathrm{~min}$ at room temperature $\left(25^{\circ} \mathrm{C}\right)$. The cooking yield was calculated based on the sample weight before and after cooking using the following equation:

$$
\text { Cooking yield }(\%)=[\text { Weight after cooking }(\mathrm{g})] /[\text { Weight before cooking }(\mathrm{g})] \times 100
$$

\section{Water holding capacity (WHC)}

Three grams of sample were wrapped in a filter paper (Whatman No. 2) and placed in a conical tube for 10 min of centrifugation at 1,000 RPM in a centrifuge (Supra R22, Hanil, Daejeon, Korea). The WHC was calculated based on the sample weight before and after centrifugation, using the following equation:

$$
\begin{gathered}
\text { WHC }(\%)=(\mathrm{A}-\mathrm{B}) /(\mathrm{A}) \times 100 \\
\mathrm{~A}=[\text { Weight before centrifugation }(\mathrm{g}) \times \text { Moisture content }(\%)] / 100 \\
\mathrm{~B}=\text { Weight before centrifugation }(\mathrm{g})-\text { Weight after centrifugation }(\mathrm{g})
\end{gathered}
$$

Here, the moisture content was estimated using the same method as the approximate composition.

\section{Texture profile analysis}

The physical properties of the sample were measured using the texture analyzer (TA 1, Lloyd, FL, USA). The cooked sample was cut to $2.5 \times 2.5 \times 2.0 \mathrm{~cm}$ (width $\times$ length $\times$ height) in size, and the measurements were taken at room temperature. The following conditions were used for analysis: pre-test speed $2.0 \mathrm{~mm} / \mathrm{s}$, post-test speed $5.0 \mathrm{~mm} / \mathrm{s}$, maximum load $2 \mathrm{~kg}$, head speed $2.0 \mathrm{~mm} / \mathrm{s}$, distance $8.0 \mathrm{~mm}$, and force $5 \mathrm{~g}$. A $25 \mathrm{~mm}$ cylinder probe was used for measurements. The measured hardness $(\mathrm{kg})$, springiness, and cohesiveness were recorded, and based on the data, the gumminess $(\mathrm{kg})$ and chewiness $(\mathrm{kg})$ were estimated.

\section{Viscosity}

The viscosity of the emulsion sausage was measured using a rotary viscometer (Rheosys, Hamilton, NJ, USA. A $30 \mathrm{~mm}$ parallel plate with a $2.0 \mathrm{~mm}$ gap was installed and set to $20 \mathrm{RPM}$ head speed to take measurements for $60 \mathrm{sec}$ at $25^{\circ} \mathrm{C}$. 


\section{Statistical analysis}

All data were analyzed using Mixed model in SAS (version 9.3), and the results are expressed as mean values. Significant differences $(p<0.05)$ among the mean values were determined using ANOVA and Duncan's multiple range test. The CORR procedure from the SAS package was used to calculate correlations between viscosity and cooking yield.

\section{RESULTS AND DISCUSSION}

\section{Proximate composition of fish meat sausage}

Table 2 presents the approximate composition of the sausage based on the mixing ratio between the carp and pork meat. The moisture content was significantly higher in $\mathrm{C} 10$ than in other test groups $(p<0.05)$, likely due to the higher moisture content of carp meat than that of pork. The result agreed with that of Jin et al. [12], where the meat of the surimi fish had high moisture content at 80.09\%-80.56\%. The protein content was significantly lower in C10 than in other test groups $(p<$ $0.05)$, likely because the higher moisture content of carp meat led to a relatively lower protein content. The fat content was the highest in $\mathrm{P} 5 \mathrm{C} 5(p<0.05)$, while $\mathrm{C} 10$ had the lowest fat content. This may be attributed to the low fat content of fish meat itself [13]. The ash content was significantly high in both $\mathrm{P} 5 \mathrm{C} 5$ and $\mathrm{C} 10(p<0.05)$, which is thought to be caused by the inherent high content of minerals in fish meat [14].

\section{$\mathrm{pH}$ and color of fish meat sausage}

Table 3 presents the $\mathrm{pH}$ and color of the sausage based on the mixing ratio between the carp and pork meat. The $\mathrm{pH}$ of samples before and after cooking increased with increase in carp content, with $\mathrm{C} 10$ displaying significantly higher $\mathrm{pH}$ values than other test groups $(p<0.05)$. This may be accounted for by the $\mathrm{pH}$ of carp (7.23), which is higher than the $\mathrm{pH}$ of pork (5.9) after rigor mortis, as reported by Bendall and Swatland [15]. The $\mathrm{pH}$ of the sausage was higher after cooking than before cooking, which was previously reported to be due to the mass release of cations from amino acid residues following protein heat denaturation [16].

The lightness before and after cooking was significantly higher in the two groups with carp than in the pork-only group $(p<0.05)$, likely because carp muscle is a white muscle with low content of myoglobin [17]. The yellowness before and after cooking was significantly higher in the pork-only group than in those with carp, and was inversely proportional to the content of red meat $(\mathrm{p}<0.05)$. The redness of the sausage after cooking decreased with increasing carp content, because carp muscle is low in nitroso-myoglobin content. P5C5 had the highest value of yellowness after cooking, and was significantly different from P10. The result is consistent with that of Yoon et al. [18], in which lightness and yellowness increased in steak after the addition of white flounder meat.

Table 2. Comparison of approximate composition of meat batters prepared with carp muscle and pork

\begin{tabular}{lcccc}
\hline \multicolumn{1}{c}{ Traits } & P10 & P5C5 & C10 & SEM \\
\hline Moisture content (\%) & $61.86^{\mathrm{b}}$ & $63.14^{\mathrm{b}}$ & $65.46^{\mathrm{a}}$ & 1.76 \\
Protein content (\%) & $14.84^{\mathrm{a}}$ & $14.58^{\mathrm{a}}$ & $13.41^{\mathrm{b}}$ & 0.63 \\
Fat content (\%) & $16.35^{\mathrm{b}}$ & $18.30^{\mathrm{a}}$ & $14.24^{\mathrm{c}}$ & 1.91 \\
Ash content (\%) & $1.56^{\mathrm{b}}$ & $1.99^{\mathrm{a}}$ & $1.93^{\mathrm{a}}$ & 0.32 \\
\hline
\end{tabular}

All values are mean $\pm \mathrm{SD}$.

${ }^{a-c}$ Means in the same row with different letters are significantly different $(p<0.05)$.

P10, 100\% pork; P5C5, 50\% pork and 50\% carp muscle; C10, 100\% carp muscle. 
Table 3. Comparison of $\mathrm{pH}$ and color of meat batters prepared with carp muscle and pork

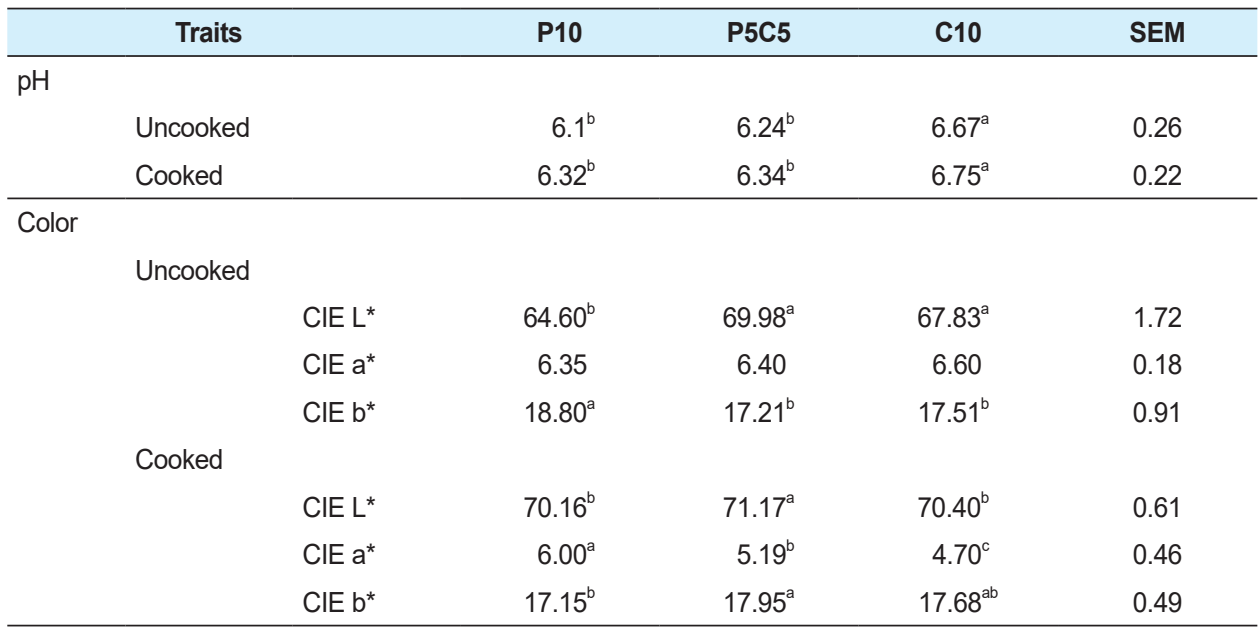

All values are mean.

${ }^{a-c}$ Means in the same row with different letters are significantly different $(p<0.05)$.

P10, 100\% pork; P5C5, 50\% pork and 50\% carp muscle; C10, 100\% carp muscle.

\section{WHC and cooking yield of fish meat sausage}

Fig. 1 shows the WHC and cooking yield of the sausage based on the mixing ratio between the carp and pork meat. The highest WHC was found in C10 compared to other test groups $(p<0.05)$. Although red meat has an abundance of sarcoplasmic proteins in comparison to white meat [19], the $\mathrm{pH}$ of $\mathrm{C} 10$ (6.67) led to a greater change away from the isoelectric point upon a high level of WHC, which may explain this result. Conversely, P5C5 and P10 did not show a significant difference, and $\mathrm{C} 10$ showed significantly higher results than other test groups. When a small amount of edible salt is added to fish meat that consists of muscle fibers, myofibrils, and acto-myosin filaments, the myosin constituting the myofibrils undergoes isolation to allow for a high level of binding [20]. This might be the reason why $\mathrm{C} 10$, which contained fish meat, showed the highest $\mathrm{WHC}$ value.

The cooking yield was significantly lower in P10 than in $\mathrm{C} 10(p<0.05)$, and $\mathrm{C} 10$ had a higher

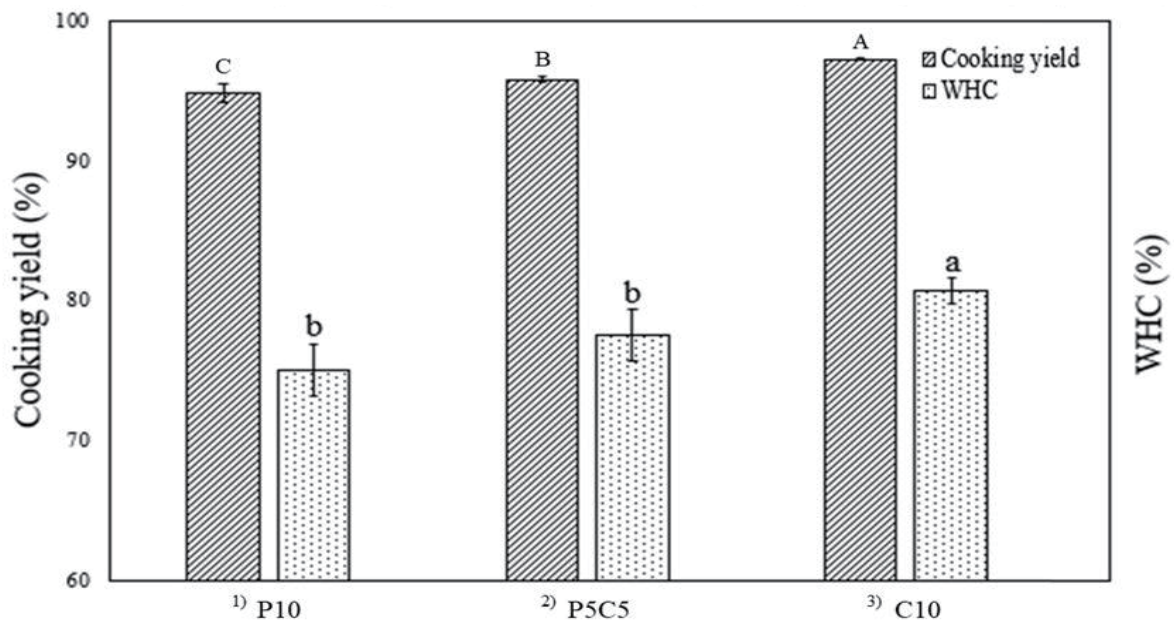

Fig. 1. Comparison of cooking yield and WHC of meat batters prepared with carp muscle and pork. All values are means. ${ }^{a, b}$ Means in the same method with different letters are significantly different $(p<0.05)$. ${ }^{\mathrm{A}-\mathrm{C}}$ Means in the same method with different letters are significantly different $(p<0.05)$. P10, $100 \%$ pork; P5C5, $50 \%$ pork and $50 \%$ carp muscle; $\mathrm{C} 10,100 \%$ carp muscle; $\mathrm{WHC}$, water holding capacity. 
value than $\mathrm{P} 5 \mathrm{C} 5$. This is probably due to the higher $\mathrm{WHC}$ of the red muscle in pork meat compared to that of the white muscle in carp meat, leading to stronger binding among the water molecules in the carp proteins than in pork proteins, consequently increasing the cooking yield.

Kristinsson and Rasco [21] reported that fish protein hydrolysates have high solubility, water retention ability, emulsification, and foam-forming ability. Thus, it is considered that the pork sausage added with fish meat can have improved WHC and cooking yield due to gelation of protein.

\section{Viscosity and texture profile analysis (TPA) of fish meat sausage}

Most fluids are characterized by non-Newtonian viscosity, which is divided into pseudoplastic, dilatant, and thixotropic. The viscosity of the sausage as determined by the mixing ratio between the carp and pork meat (Fig. 2) corresponds to time-dependent thixotropic viscosity [22]. C10 had a higher value than $\mathrm{P} 5 \mathrm{C} 5$, which itself had a higher value than $\mathrm{P} 10$. This is due to the inherent gelation ability of the carp muscle and the combining ability of sausage based on viscoelasticity [23], which is a critical property relating to the quality of fish meat paste products. It is thus anticipated that a product with enhanced binding and texture properties may be produced by adding carp meat.

Table 4 presents the results of TPA for the sausages based on the mixing ratio between the carp and pork meat. In the texture profile of the fish meat sausages, elasticity is the most important

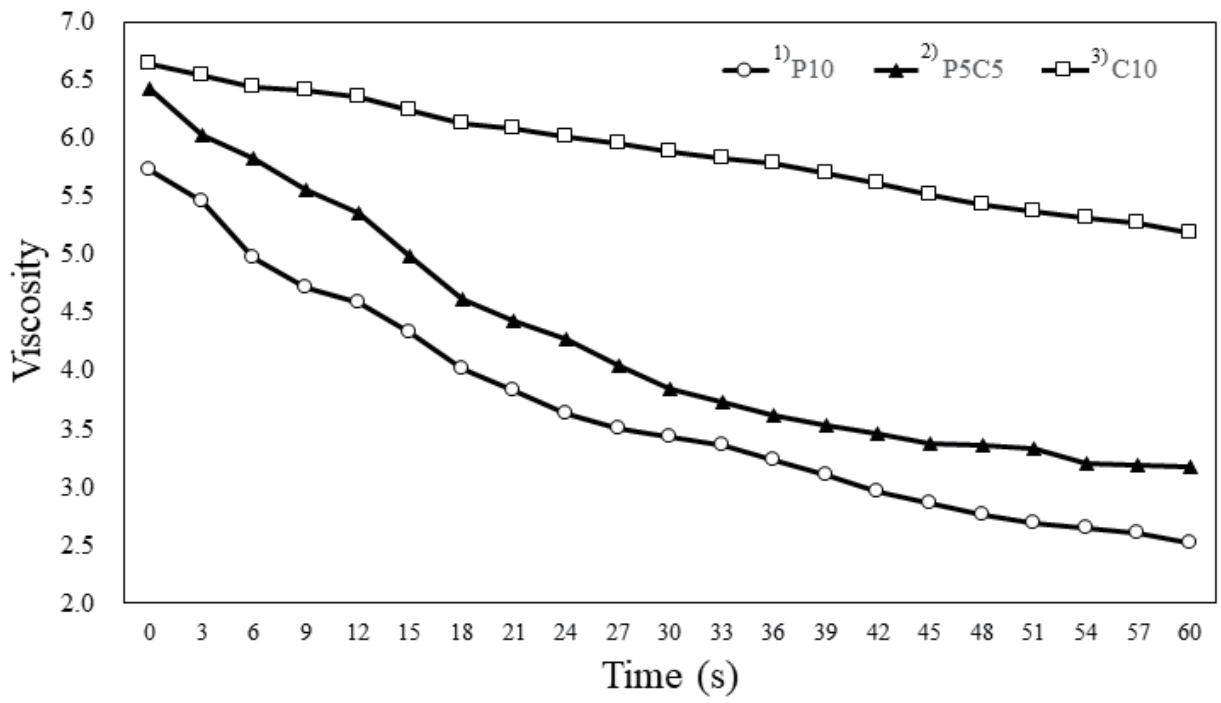

Fig. 2. Change in the apparent viscosity of meat batters prepared with carp muscle and pork. $\mathrm{P} 10,100 \%$ pork; P5C5, 50\% pork and 50\% carp muscle; C10, 100\% carp muscle.

Table 4. Comparison of TPA of meat batters prepared with carp muscle and pork

\begin{tabular}{lllll}
\hline \multicolumn{1}{c}{ Traits } & P10 & P5C5 & C10 & SEM \\
\hline Springiness & $0.62^{\mathrm{b}}$ & $0.70^{\mathrm{ab}}$ & $0.75^{\mathrm{a}}$ & 0.13 \\
Hardness $(\mathrm{kg})$ & $1.98^{\mathrm{a}}$ & $7.48^{\mathrm{b}}$ & $7.31^{\mathrm{b}}$ & 5.34 \\
Gumminess $(\mathrm{kg})$ & $1.35^{\mathrm{a}}$ & $0.43^{\mathrm{b}}$ & $0.16^{\mathrm{b}}$ & 0.39 \\
Chewiness $(\mathrm{kg})$ & $0.83^{\mathrm{a}}$ & $0.29^{\mathrm{b}}$ & $0.34^{\mathrm{b}}$ & 0.23 \\
Cohesiveness & $0.70^{\mathrm{a}}$ & $0.58^{\mathrm{b}}$ & $0.65^{\mathrm{a}}$ & 0.08 \\
\hline
\end{tabular}

All values are mean.

${ }^{a-c}$ Means in the same row with different letters are significantly different $(p<0.05)$.

P10, $100 \%$ pork; P5C5, 50\% pork and 50\% carp muscle; C10, 100\% carp muscle. 


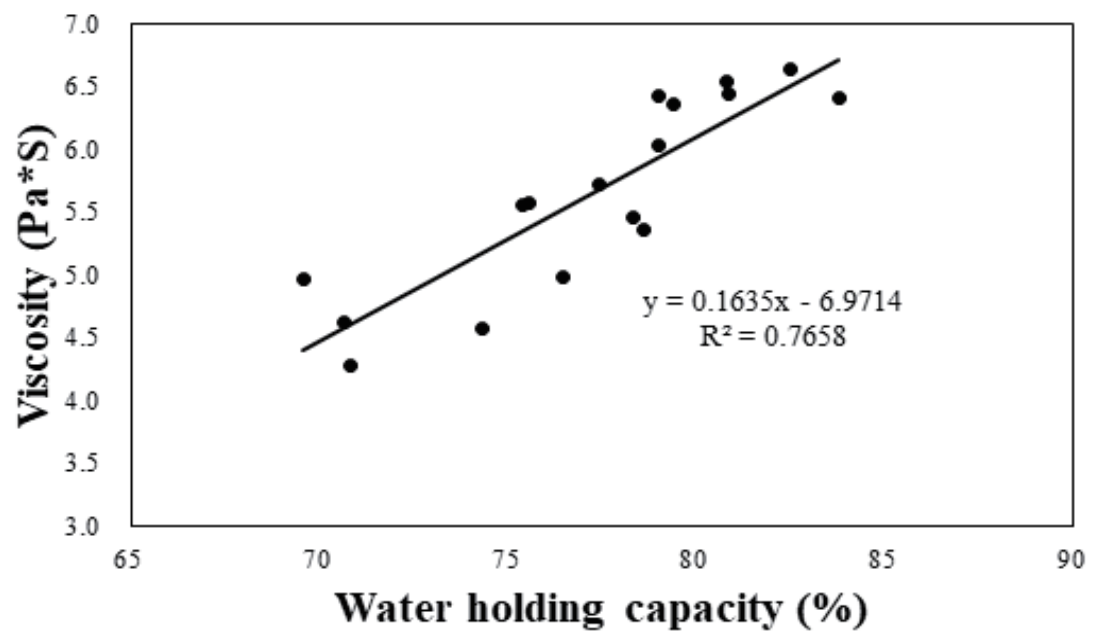

Fig. 3. Relationship between water holding capacity and viscosity of meat batters prepared with carp muscle and pork. P10, 100\% pork; P5C5, 50\% pork and 50\% carp muscle; C10, 100\% carp muscle.

factor [24]. Springiness increased as the carp meat content increased, and a significant difference was found between P10 and $\mathrm{C} 10(p<0.05)$. This is presumed to be caused by the higher moisture content in carp meat than in pork meat. P10 sausages had significantly higher gumminess and chewiness values than those containing carp meat, likely due to the influence of hardness [25]. Further, $\mathrm{P} 10$ and $\mathrm{C} 10$ had significantly higher cohesiveness values than P5C5. Based on the findings of this study, a fish meat sausage product can be produced to resemble the existing products, but with higher WHC due to the reticular structure of carp protein, and with enhanced elasticity.

\section{Relationship between viscosity and water holding capacity of fish meat sausage}

Fig. 3 shows the correlation between WHC and viscosity of the sausage based on the mixing ratio between the carp and pork meat. With increased emulsion viscosity in the pork and carp meat, the WHC had an increasing trend $\left(R^{2}=0.7658\right)$ and a high correlation, followed by an increase towards a proportional relationship. According to Huff-Lonergan and Lonergan [27], the WHC as an ability to retain moisture is the most important factor in maintaining the physicochemical quality. In addition, viscosity is influenced by the shape of the salt soluble protein, which reportedly has a significant impact on the maintenance of the overall shape of the sausage [28]. Thus, it is anticipated that a product of outstanding quality can be developed by adding carp meat based on the proportional increase in $\mathrm{WHC}$ and viscosity.

\section{CONCLUSION}

The results of this research suggest that carp meat can enhance the quality of emulsion sausages. Carp muscle not only improved cooking yield, but also enhanced viscosity and texture profile analysis because of its high WHC. Therefore, sausages may be manufactured with carp meat to supplement or overcome the disadvantages of pork.

\section{REFERENCES}

1. Yoon SS, Cho WJ, Chung YJ, Cha YJ. Studies on the prediction of shelf-life of commercial fish paste products. J Korean Fish Soc. 2001;34:652-5. 
2. Pacheco-Aguilar R, Crawford DL, Lampila LE. Procedures for the efficient washing of minced whiting (Merluccius products) flesh for surimi production. J Food Sci. 1989;54:248-52. https://doi.org/10.1111/j.1365-2621.1989.tb03054.x

3. Jin SK, Kim IS, Nam YW, Park SC, Choi SY, Yang HS, et al. Comparison of textural properties of crab-flavored sausage with different proportions of chicken meat. Korean J Food Sci Anim Resour. 2008;28:395-400. https://doi.org/10.5851/kosfa.2008.28.4.395

4. Tanikawa E. Fish sausage and ham industry in Japan. Adv Food Res. 1963;12:367-424. https:// doi.org/10.1016/S0065-2628(08)60011-7

5. Benjakul S, Visessanguan W, Thongkaew C, Tanaka M. Effect of frozen storage on chemical and gel-forming properties of fish commonly used for surimi production in Thailand. Food Hydrocoll. 2005;19:197-207. https://doi.org/10.1016/j.foodhyd.2004.05.004

6. Yang ST, Lee EH. Fish jelly forming ability of frozen and ice stored common carp and conger eel. Bull Korean Fish Soc. 1985;18:44-51.

7. Choi GH. Process for making food for good health from snakehead and crucian carp. Korea patent 10-1992-010606. 1992 Jun 18.

8. Kawk HW. A manufacturing method of instant soup with skate. Korea patent 10-10250600000. 2008 May 7.

9. Goo JG, Shin JK. Crucian steamed foods, and its manufacturing method. 2017. Korea patent 10-1775786-0000.2015 Oct 13.

10. Murai T, Akiyama T, Nose T. Effect of amino acid balance on efficiency in utilization of diet by fingerling carp. Nippon Suisan Gakkai Shi. 1984;50:893-7. https://doi.org/10.2331/suisan. 50.893

11. AOAC [Association of Official Analytical Chemists]. Official methods of analysis. 15 th ed. Washington, DC: Association of Official Analytical Chemists; 1990.

12. Jin SK, Kim IS, Yang HS, Choi YJ, Kim BG. Quality characteristics of surimi manufactured by Alaska pollack, barren hen breast meat and mechanically deboned chicken meat.J Anim Sci Technol. 2007;49:395-404. https://doi.org/10.5187/JAST.2007.49.3.395

13. Kim JY, Hwang EY, Lee JH, Ryu HS. Protein nutritional qualities of beef patties added with crucian carp extraction residue. J Korean Soc Food Sci Nutr. 2001;30:488-93.

14. Toppe J, Albrekten S, Hope B, Aksnes A. Chemical composition, mineral content and amino acid and lipid profiles in bones from various fish species. Comp Biochem Physiol Part B Biochem Mol Biol. 2007;146:395-401. https://doi.org/10.1016/j.cbpb.2006.11.020

15. Bendall JR, Swatland HJ. A review of the relationship of $\mathrm{pH}$ with physical aspects of pork quality. Meat Sci. 1988;24:85-126. https://doi.org/10.1016/0309-1740(88)90052-6

16. Forrest JC, Aberle ED, Hedrick HB, Judge MD, Merkel RA. Principle of meat processing. In: Principles of meat science. San Francisco, CA: W. H. Freeman and Company; 1975. p. 190226.

17. Lawrie RA. Biochemical differences between red and white muscle. Nature. 1952;170:122-3. https://doi.org/10.1038/170122a0

18. Yoon MJ, Lee JD, Kang KH, Park SY, Joo JC, Kim JG. Processing and quality properties of olive flounder paralichthys olivaceus steak added with pork leg. Korean J Fish Aquat Sci. 2015;48:849-56. https://doi.org/10.5657/KFAS.2015.0849

19. Park JD, Jung CH, Kim JS, Cho DM, Cho MS, Choi YJ. Surimi processing using acid and alkali solubilization of fish muscle protein. J Korean Soc Food Sci Nutr. 2003;32:400-5. https:// doi.org/10.3746/jkfn.2003.32.3.400

20. Lee YS, Jeong Y, Yoo B. Effect of transglutaminase on the rheological properties of fried surimi gel. Korean J Food Sci Technol. 2001;33:474-8. 
21. Kristinsson HG, Rasco BA. Fish protein hydrolysates: production, biochemical, and functional properties. Crit Rev Food Sci Nutr. 2000;40:43-81. https://doi.org/10.1080/10408690091189266

22. Mewis J, Wagner NJ. Thixotropy. Adv Colloid Interface Sci. 2009;147-8:214-27. https://doi. org/10.1016/j.cis.2008.09.005

23. Surh JH, Ward LS, McClemets DJ. Ability of conventional and nutritionally-modified whey protein concentrates to stabilize oil-in-water emulsions. Food Res Int. 2006;39:761-71. https:// doi.org/10.1016/j.foodres.2006.01.007

24. Ducept F, Brouker T, Souliè JM, Trystram G, Cuvelier G. Influence of the mixing process on surimi seafood paste properties and structure. J Food Eng. 2012;108:557-62. https://doi. org/10.1016/j.jfoodeng.2011.09.006

25. Seo JS, Cho HS. Quality characteristics of fish paste with shrimp powder. Korean J Food Preserv. 2012;19:519-24. https://doi.org/10.11002/kjfp.2012.19.4.519

26. Delgado P, Bañón S. Determining the minimum drying time of gummy confections based on their mechanical properties. CyTA J Food. 2015;13:329-35. https://doi.org/10.1080/19476337. 2014.974676

27. Huff-Lonergan E, Lonergan SM. Mechanisms of water-holding capacity of meat: the role of postmortem biochemical and structural changes. Meat Sci. 2005;71:194-204. https://doi. org/10.1016/j.meatsci.2005.04.022

28. Ramírez JA, Uresti RM, Velazquez G, Vázquez M. Food hydrocolloids as additives to improve the mechanical and functional properties of fish products: a review. Food Hydrocoll. 2011;25:1842-52. https://doi.org/10.1016/j.foodhyd.2011.05.009 